$\mathrm{A} J_{\text {ars }} \mathrm{H}$

Received : 31.12.2014

Revised : 13.11 .2015

Accepted : 24.11.2015
Members of the Research Forum

Associated Authors:

${ }^{1}$ Bihar Agricultural University,

Sabour, BHAGALPUR (BIHAR) INDIA
THEASIAN JOURNALOF HORTICULTURE

Volume 10 | Issue 2 | December, 2015 | 278-281

Visit us -www.researchjournal.co.in

RESEARCH PAPER

DOI : 10.15740/HAS/TAJH/10.2/278-281

\title{
Evaluation of cultivars of strawberry, a temperate fruit for its adaptability as well as productivity in sub-tropical agro-climatic condition of Supaul district in Bihar
}

\section{A.K. DAS ${ }^{1}$, K.P. SINGH, B. PRASAD ${ }^{1}$ AND RAVINDRA KUMAR ${ }^{1}$}

ABSTRACT : The findings of a field trial conducted in 2012-13 and 2013-14 to assess different cultivars of strawberry in Supaul district of Bihar revealed that short day cultivars were more tolerant to insect pests than day neutral cultivars, particularly in later stage of fruit development leading to record higher yield. It was also revealed that a suitable micro-climate was required for optimum plant growth, higher crop yield and the best quality fruits. Festival was found to be the best performing variety in respect of weight per fruit, yield and marketable fruit quality having maximum growth, plant height $(21.34 \mathrm{~cm})$, flowering duration (60.09 days), fruiting duration (55.62 days) and yield (15.26 tons/ha).

KEY WORDS : Strawberry, Festival, Camarosa, Sweet charlie

Author for correspondence : K.P.SINGH

Bihar Agricultural University,

Sabour, BHAGALPUR (BIHAR) INDIA
HOW TO CITE THIS ARTIClE : Das, A.K., Singh, K.P., Prasad, B. and Kumar, Ravindra (2015). Evaluation of cultivars of strawberry, a temperate fruit for its adaptability as well as productivity in subtropical agro-climatic condition of Supaul district in Bihar. Asian J. Hort., 10(2) : 278-281. 